\title{
Zoran Jelenc \\ IZOBRAŽEVANJE ODRASLIH V SLOVENIJI PRED TRANZICIJO IN PO NJEJ
}

\section{POVZETEK}

Po letu 1991, ko je Slovenija postala samostojna, je država z več sistemskimi ukrepi podprla razvoj izobraževanja odraslih: v državnem proračunu odobrena posebna sredstva za izobraževanje odraslih; ustanovljen sektor za izobraževanje odraslih na ministrstvu za šolstvo; sprejet poseben zakon o izobraževanju odraslih; ustanovljena posebna strokovna ustanova za razvoj in pospeševanje razvoja izobraževanja odraslih; zasnovan nacionalni program za izobraževanje odraslih; oblikovan program visokošolskega študija andragogike; začele delovati številne zasebne organizacije za izobraževanje odraslih; nastala nova združenja za izobraževanje odraslih; začela izhajati strokovna in znanstvena revija za izobraževanje odraslih; stekli številni razvojni in raziskovalni projekti, namenjeni razvijanju in pospeševanju kulture učenja. Sprejeta je Strategija vseživljenjskosti učenja v Sloveniji. Kljub temu izobraževanje odraslih $v$ Sloveniji sistemsko še ni ustrezno urejeno; ostaja na ravni, na kateri smo bili pred tremi ali štirimi desetletji.

Ključne besede: izobraževanje odraslih, sistemsko urejanje vzgoje in izobraževanja, strategija vseživljenjskosti učenja, razvoj in zgodovina izobraževanja odraslih, politika vzgoje in izobraževanja

\section{ADULT EDUCATION IN SLOVENIA BEFORE AND AFTER THE TRANSITION PERIOD - ABSTRACT}

After Slovenia became an independent country in 1991, the government put in place several systemic measures to support the development of adult education: funding for adult education was set up in the state budget, the Sector for Adult Education was established at the Ministry of Education; legislation on adult education was passed; an institution to facilitate the development of adult education was established; a national adult education programme was designed; a university programme in andragogy was founded; several private adult education organisations began operating, new adult education associations were created; a scientific journal on adult education started to be published; numerous developmental and research projects were launched with the aim of facilitating and furthering the culture of learning. The Lifelong Learning Strategy was passed. Despite all this, adult education in Slovenia is still not adequately system edited; it is still at the level it was three or four decades ago.

Keywords: adult education, education system edition, lifelong leraning strategy, adult education history and development, education policy

Dr. Zoran Jelenc, Andragoško društvo Slovenije, zoran.jelenc@guest.arnes.si 


\section{UVOD}

Pri primerjavi stanja izobraževanja odraslih $\mathrm{v}$ obdobju Jugoslavije s tistim po razpadu nekdanje skupne države se bomo $\mathrm{v}$ tem prispevku omejili na sisteme in politike izobraževanja odraslih in stanje v Sloveniji. Stanje v Sloveniji po razpadu Jugoslavije se gotovo pomembno razlikuje od stanja $\mathrm{v}$ drugih novonastalih državah, ki so sestavljale nekdanjo skupno državo; razlogov za to je več, a najpomembnejši je ta, da je slovenska vlada ob osamosvojitvi Slovenije sprejela vrsto ukrepov za razvoj izobraževanja odraslih (o čemer več v nadaljevanju). Za večjo uspešnost primerjave bomo prikazali sistem izobraževanja odraslih in posebnosti njegovega razvoja tudi širše, pri nas in deloma tudi v svetu. Analiziramo dostopne zgodovinske vire in opravljene raziskave, pri čemer se osredotočamo na začetno obdobje razvoja izobraževanja odraslih, obdobje med obema vojnama, obdobje po drugi svetovni vojni, ko je bil razvoj izobraževanja odraslih pri nas tesno povezan z razvojem izobraževanja odraslih v Jugoslaviji, ter na obdobje po osamosvojitvi Slovenije. Z zgodovinsko analizo sistemskega urejanja in politike izobraževanja odraslih ugotavljamo, da smo v Sloveniji kljub sorazmerno uspešnemu razvoju izobraževanja odraslih v praksi pri sistemskem urejanju tega področja še vedno ostali na ravni, na kateri smo bili pred tremi ali štirimi desetletji.

\section{SISTEMSKO UREJANJE IZOBRAŽEVANJA ODRASLIH V SVETU}

Obravnavo tematike moramo začeti z ugotovitvijo, da izobraževanje odraslih po svoji sistemski urejenosti - umestitev v sistem, zakonodaja, upravljanje, financiranje, ponudba izvajalcev in programov ter infrastruktura - nima daljše tradicije, kakršno ima po svoji razvitosti in delovanju v praksi ter po sistemski urejenosti izobraževanje otrok in mladine. Analogno tudi andragogiki, znanstveni disciplini o izobraževanju odraslih, niso namenjali tolikšne pozornosti kot pedagogiki, če jo pojmujemo ožje kot znanstveno disciplino o izobraževanju otrok in mladine. Večjo pozornost do andragogike in izobraževanja odraslih ter sistemskega urejanja tega področja opažamo v politiki vzgoje in izobraževanja šele v drugi polovici preteklega stoletja (Knowles, 1980). Celo temeljitejša in za večino strokovnjakov še kar sprejemljiva opredelitev izobraževanja odraslih je stara komaj dobrih 40 let. Sprejemljiva pa je le zato, ker je zelo vseobsegajoča, široko zajema in poskuša povezati različne možnosti izobraževanja odraslih, ne da bi jih umeščala v sistem. To je znana opredelitev, ki jo je sprejela generalna skupščina Unesca na svojem zasedanju v Nairobiju leta 1976 (Unesco, 1976). ${ }^{1}$

Diana Ironside (v Titmus, 1989b, str. 13) ugotavlja, da izobraževanje odraslih vse do osemdesetih let prejšnjega stoletja ni bilo obravnavano kot ločeno področje (sektor)

1 Opredelitev, sprejeta na generalni skupščini Unesca, je: »Izobraževanje odraslih je celota organiziranih izobraževalnih procesov katere koli vsebine, stopnje in uporabljenih metod, bodisi formalno ali drugačno bodisi da nadaljuje ali nadomešča začetno izobraževanje $\mathrm{v}$ šolah, kolidžih in univerzah, $\mathrm{z}$ oblikami usposabljanja vred. V teh procesih osebe, ki jih v posameznih družbah štejejo za odrasle, razvijajo svoje zmožnosti, bogatijo znanje, zboljšujejo ali spreminjajo strokovno in poklicno usposobljenost, stališča in vedenje, da bi se lahko polnovredno osebnostno razvijale in sodelovale pri oblikovanju uravnoteženega in neodvisnega socialnega, gospodarskega in kulturnega razvoja.« 
izobraževanja in ga mnoge države priznavajo kot takšno šele v zadnjem času, a tudi tedaj ga številne niso obravnavale ustrezno. Namesto da bi govorili o celotnem sistemu izobraževanja odraslih in o vseh njegovih razsežnostih v medsebojni povezanosti, se je govorilo in se marsikje še govori, pravi avtorica, le o posameznih področjih (zvrsteh) izobraževanja odraslih, predvsem tako, kot so se zaznavala in dojemala v praksi, denimo o »sindikalnem izobraževanju«, »izobraževanju delavcev«, »liberalnem izobraževanju « itn. Za izobraževanje odraslih je značilno, da je »prihajalo iz prakse«, in za to »prihajanje« je značilno, da se pojavlja takšno, kakršno se je lahko razvilo v vsakokratnih posebnih okoliščinah v praksi, ki se seveda tem okoliščinam prilagaja. Na nehomogenost področja je gotovo vplivalo tudi to, da za izobraževanje odraslih ni bilo veliko posebnih programov dodiplomskega študija andragogike (izobraževanja odraslih) ter da tako ni bilo mogoče sistematično oblikovati in razvijati strokovnega osebja za to področje. ${ }^{2}$ Tako niso mogle nastajati niti se niso mogle prenašati enotne strokovne doktrine in znanstvene paradigme o izobraževanju odraslih in andragogiki, ki bi lahko bile podlaga za teoretično delo na tem področju in za njegovo konceptualizacijo. Kot vemo, je bila v preteklosti skoraj vsa pozornost raziskovalcev namenjena izobraževanju in vzgajanju otrok in mladine. Tako so praznino, pomanjkanje andragoško usposobljenega strokovnega osebja, zapolnjevale druge stroke, kot so psihologija, sociologija, organizacijske vede in še številne druge, seveda poleg pedagogike, ki pa strokovnjakov ni usposabljala s posebno pozornostjo do značilnosti in specifičnosti izobraževanja odraslih. ${ }^{3}$ Tega gotovo ne moremo označevati le kot negativno okoliščino, temveč je nedvomno imelo številne ugodne učinke na razvoj izobraževanja odraslih in andragogike: omogočilo je njegovo raznovrstnost in s tem bogastvo, hkrati pa seveda preprečevalo njegovo konceptualizacijo in oblikovanje v enoten sistem. V izobraževanje odraslih so se tako predvsem vnašale mnoge dobre, lahko pa tudi slabe izkušnje iz drugih strok, te pa so se doslej manj zgoščevale v enotno andragoško teoretično shemo.

O možnostih koncipiranja in sistemskega urejanja izobraževanja odraslih, ki ga Titmus (1989c, str. 381-387) rajši poimenuje »formalno strukturiranje« pa tudi »oblikovanje nacionalnega sistema«, imenovani avtor ugotavlja, da v nobeni državi na svetu (kot edino izjemo navaja Kitajsko, a tega podrobneje ne pojasnjuje) ni bilo izobraževanje odraslih trajneje sistemsko urejeno; nobena država ni imela nacionalnega sistema izobraževanja odraslih, to je »koherentne celote $\mathrm{z}$ med seboj povezanimi deli «. Vendar Titmus ob tem $\mathrm{z}$ navedbo, da velja to $» \mathrm{~V}$ najboljšem primeru $«$ - tudi nakazuje, da so se v nekaterih drŽavah premikali od »konglomeracije k organski celoti«. To lahko označimo kot napredek tudi v Titmusovih stališčih do možnosti oblikovanja izobraževanja odraslih kot sistema. Desetletje prej (Titmus, 1979) je namreč zapisal, da je to, kar imenujemo izobraževanje

2 Diana Ironside (v Titmus 1989b, po Jenson 1964) navaja, da se je izobraževanje odraslih kot stopenjski študij prvič pojavilo leta 1930 v Severni Ameriki.

3 Značilno je, da je večina »vélikih andragogov « starejšega in zdaj srednjega rodu v 20. stoletju (npr. Lindeman, Knowles, Kidd, Freire, Tough, Jarvis, Titmus) bodisi prišla iz drugih strok bodisi vstopila v izobraževanje odraslih iz prakse, potem ko so na začetku svoje kariere delali v kaki drugi dejavnosti (Jelenc, 2016, str. 72). 
odraslih, sestavljeno iz tako različnih dejavnosti, »da so interakcije med njimi komaj kaj večje kot tiste minimalne, ki v neki družbi obstajajo med enim in drugim poljubnim družbenim pojavom«. Različne države so pri tem gibanju dosegle različno stopnjo, to pa kaže na nedokončan proces, ki še poteka.

Od tega, da se je izobraževanje odraslih obravnavalo le kot nekaj, kar je dodatno pomembno v nacionalni politiki, do tega, da ga je začela država dejavneje upoštevati, se je moral zgoditi preskok, ki ni bil odvisen le od izobraževanja odraslih. K temu je pripomoglo predvsem postopno sprejemanje načel vseživljenjskosti učenja, ki je delovalo integrativno. Potreba po integraciji mora zajeti vsa področja izobraževanja, če hoče biti uresničena kot načelo za oblikovanje celotnega sistema izobraževanja. Integracija ima horizontalno in vertikalno razsežnost. V njej je dobila svoje mesto tudi zamisel o izobraževanju odraslih kot koherentni celoti.

Izobraževanje odraslih - kot pojem in tudi kot skupni koncept - je bolj »posledica racionalizacije«, torej iskanja skupnega smisla po dogodku, pobudi, potrebi itn., kot pa »sistematičnega uresničevanja vnaprej postavljenih načel«. Takšna skupna načela bi lahko postavile osrednje državne oblasti, to pa bi pomenilo, da bi posegle v raznolikost in avtonomnost pojavnosti izobraževanja odraslih. To se po Titmusovem mnenju (1989b) v resnici dogaja pri začetnem izobraževanju (šolanju otrok in mladine) in posledice tako usmerjene politike so vse prej kot ugodne (togost, uniformnost, neinventivnost itn.). Državno centralizirano vodenje politike izobraževanja odraslih je bilo doslej bolj značilno za nekdanje socialistične države, med temi tudi za Jugoslavijo, kjer so vlade in unitaristične politične sile usmerjale razvoj celotnega izobraževanja in tudi izobraževanja odraslih iz ideoloških in pragmatičnih razlogov, da bi tako povečevale moč svojega usmerjanja in nadzora. V razvitih državah na zahodu pa so prevladovala načela bogate, večidel zasebne ponudbe, avtonomnosti udeleženih subjektov, sodelovanja pri odločanju, decentralizacije in vpliva lokalnih dejavnikov, tekmovalnosti itn., kar vse zmanjšuje možnosti osrednje države pri snovanju in izpeljevanju sistemskih rešitev.

Spričo navedenih značilnosti so se nacionalni sestavi izobraževanja odraslih razlikovali od države do države. To se morda najznačilneje zrcali v tem, da so se zelo redke države odločile za samostojen in poseben zakon za celotno izobraževanje odraslih (npr. Norveška in Japonska). Države so še zmeraj urejale to področje z zakoni za posamezna področja. Pogosto je bila najbolj opazna, če ne edina mogoča regulacija, da je država uporabila finančna sredstva. Dodelitev ali nedodelitev denarja je poglavitni instrument državnega nadzora. Ta nedvomno učinkovito vpliva na možnosti izpeljave izobraževanja odraslih, kar se zrcali celo v vsebini ali vsebinski sestavi izpeljanih programov, s tem pa posega tudi v razmere na trgu izobraževanja - vpliva na ponudbo in povpraševanje.

Pa vendar ne glede na svoj dvom in kritičnost glede pozitivne vloge države pri razvijanju »formalnih struktur« ali pri oblikovanju nacionalnih sistemov izobraževanja odraslih Titmus (1989c, str. 384-387) le vidi možnost, da bi vsaj konceptualno opredelili »ogrodje nacionalnih struktur«. Pri tem opredeljuje načela, namene, vsebine, izvajalske 
organizacije, odločanje, financiranje ter povezovanje med izobraževanjem odraslih in drugimi deli izobraževanja. Iz prikaza navedenih postavk lahko ugotovimo, koliko lahko vsaka od njih spodbudi potrebo po oblikovanju nacionalnih sistemov izobraževanja odraslih, in nasprotno, koliko je oblikovanje nacionalnega sistema nujen pogoj, da se posamezna postavka uresniči.

Pri načelih, ki jih navaja Titmus (n. d., 1989c, str. 384), najdemo tele temeljne opredelitve:

- Načela se sprejemajo bolj ali manj kot splošnoveljavna (univerzalna), v praksi pa se morajo prilagajati možnostim in okoliščinam.

- Vsak odrasli potrebuje ustrezne možnosti za izobraževanje, ni dovolj, da mu jih le opredelimo kot pravico.

- To, da se vsak posameznik izobražuje tudi kot odrasli, je potrebno za družbo.

- Možnosti za učenje morajo biti organizirane tako, da zadostijo potrebam posameznika in družbe.

- Udeležba v izobraževanju odraslih mora biti prostovoljna.

- Izobraževanje odraslih mora biti sestavni del vseživljenjskega izobraževanja.

- Načela in izpeljava izobraževanja odraslih se morajo prilagajati temeljnim načelom družbe, katere sestavni del so, morajo pa delovati tudi tako, da krepijo temeljna načela družbe.

Ta načela kar trdno določajo pravice in možnosti posameznika pa tudi interes in dolžnosti države. Če bi jih upoštevali, bi bila konceptualizacija in oblikovanje nacionalnih sistemov izobraževanja odraslih prednostna naloga države ter njene izobraževalne in razvojne politike. Prav tako pa najbrž lahko rečemo, da bi jih bilo težko uresničiti, če jih ne bi podprl nacionalni sistem. $\mathrm{V}$ naslednjih dveh Titmusovih postavkah, tako $\mathrm{v}$ namenih kot tudi pri vsebinah, gre za področja, ki naj bi bila z uporabljeno klasifikacijo čim popolneje zajeta, tako da po možnosti ne bi nastajal kak ostanek, ki ga ne bi mogli uvrstiti v pojem izobraževanje odraslih.

Po namenu je mogoče izobraževanje odraslih po Titmusu (prav tam) razvrstiti na tale štiri področja:

- Izobraževanje kot druga priložnost vključuje vse možnosti izobraževanja, ki odraslim omogočajo, da pridobijo izobrazbo, ki bi jo sicer lahko pridobili ali bi jo morali pridobiti na stopnji začetnega izobraževanja, vse od temeljne pismenosti do možnosti vstopa na univerzo ali v visokošolsko izobraževanje.

- Izobraževanje za nekatere vloge ali funkcije v družbi, ki so lahko namenjene opravljanju bodisi družbenih (državljan, član interesne skupine itn.) bodisi osebnih vlog (član družine, upokojenec itn.).

- Poklicno izobraževanje omogoča pridobitev znanja in spretnosti, ki jih potrebujemo za opravljanje dela ali poklica kot zaposlena oseba.

- Izobraževanje za osebno bogatitev je namenjeno razvoju in rasti posameznika kot osebe, ne glede na njegove druge (družbene, ekonomske, poklicne itn.) vloge. V tej kategoriji so vse vsebine, ki jih ni bilo mogoče zajeti v nobeni od prej navedenih. 
Tem štirim kategorijam je Titmus pozneje (1996, str. 14) dodal še peto, ki jo je poimenoval izobraževanje za družbeno blaginjo, vendar to le v neki smeri dopolnjuje, ne spremeni pa bistveno temeljne delitve izobraževanja odraslih, ki smo jo opisali.

Tudi iz opisanih namenov je mogoče videti, da lahko imata ali celo morata imeti interes za izobraževanje odraslih posameznik pa tudi družba. Tudi to govori v prid temu, da naj bi država imela interes za oblikovanje nacionalnega sistema izobraževanja odraslih.

Klasifikacija vsebin je še bolj kot klasifikacija namenov stvar strokovne odločitve. Ker so pri takšnih klasifikacijah mogoči različni prijemi in je temeljno načelo znova to, da je z izbrano razvrstitvijo mogoče razvrstiti vse vsebine, ki se pojavljajo pri izobraževanju in učenju odraslih, na tem mestu Titmusove klasifikacije (1989c, str. 384-385) ne bomo predstavili. Vloga ali interes države in vloga ali interes posameznika se pri vsebinah izobraževanja razlikujeta, vsak ima svoja načela selekcioniranja, vendar skupaj sestavljata celoto. Država, ki želi dobro opravljati svojo nalogo, da skrbi za občane in njihovo blaginjo, bo seveda upoštevala tudi interese posameznika in se skušala organizirati tako, da bi jih čim bolj zadovoljila, ali vsaj, da jih ne bi ovirala.

\section{SISTEMSKA (NE)UREJENOST IZOBRAŽEVANIA ODRASLIH V SLOVENIJI V RAZLIČNIH OBDOBJIH}

Za izobraževanje odraslih v Sloveniji lahko rečemo, da ni bilo do zdaj nikoli sistemsko celovito urejeno. To lahko trdimo tako za preteklost kot tudi za današnje stanje. Bila so obdobja, ko se je to urejalo parcialno, s poudarki na sistemskem urejanju posameznih področij. Poglejmo na kratko položaj in pojavnost izobraževanja odraslih v preteklosti in poskušajmo na tej podlagi opredeliti, kakšno mesto je imelo izobraževanje odraslih v tedanji vzgojno-izobraževalni politiki.

\section{V poznem srednjem veku in začetku novega veka}

Lahko rečemo, da je imelo izobraževanje odraslih na območju današnje Slovenije v poznem srednjem in zgodnjem novem veku podoben razvoj kot drugje po Evropi; zadovoljevalo je predvsem potrebe in zahteve po pisanju in branju v maternem jeziku, razvijanju pismenosti za sodelovanje $\mathrm{v}$ verskih obredih, splošni izobrazbi za krepitev etične in moralne vzgoje, pri tem je bila posebna pozornost namenjena vzgoji staršev, pomembno področje je bilo tudi umno gospodarjenje, zlasti v kmetijstvu, vinogradništvu, obrti, rokodelstvu itn.; izobraževanje je bilo potrebno tudi v čebelarstvu. Najpomembnejšo vlogo pri izobraževanju vseh ljudi ne glede na starost so imeli duhovniki, ki so bili nekakšni ljudski učitelji, ki so poleg širjenja splošne izobrazbe s tem spodbujali ljudi k poglobljenemu verskemu življenju, krepitvi krščanskega duha in moralnih vrednot. To izobraževanje, zlasti odraslih, je potekalo zunaj šol, poudarjali so samoizobraževanje, ki je imelo prednost pred šolskim, »prisilnim« izobraževanjem. Medtem ko so se v Evropi (zlasti na Danskem) začele razvijati ljudske visoke šole, so bile na območju današnje Slovenije oblika institucializacije izobraževanja odraslih (zlasti mladih, ki so iz različnih vzrokov 
izstopili iz ljudskih šol, in tudi odraslih, ki so bili pomanjkljivo izobraženi) nedeljske »nadaljevalne in ponavljalne šole «; 4 šlo je za znanje za vsakdanje življenje. Takšno razmišljanje najdemo v delih Franja Žgeča (1923) in Karla Ozvalda (1927); oba s svojimi pojmovanji in delom dokazujeta, da sta bila široko razgledana pedagoga. Žgečevo delo lahko formalno označimo kot prispevek k snovanju in razvijanju izobraževanja odraslih pri nas, zlasti po njegovem videnju in opredeljevanju omrežja izobraževalnih organizacij, ki ga v primerjavi s prej delujočo in prepoznano ponudbo na Slovenskem razširi s pomembno ustanovo za izobraževanje odraslih - ljudsko visoko šolo. Ko je izšlo Žgečevo delo, je v Sloveniji že začela delovati prva ljudska univerza (ustanovljena leta $1922 \mathrm{v}$ Mariboru). Žgečev sistem zasleduje bolj kontinuiteto izobraževanja na prehodu iz otroške dobe v mladostniško kot pa kontinuiteto med mladino in odraslimi v postmladostniških obdobjih. Ker ne omenja tudi drugih tedaj že delujočih vrst izobraževanja odraslih v Sloveniji (narodnoprosvetiteljsko, poklicni tečaji itn.), Žgeča ne moremo šteti med pedagoge, ki bi prepoznavali in obravnavali izobraževanje odraslih kot razmeroma samostojen sistem. Pač pa lahko to rečemo za sistemska razmišljanja in pojmovanje Karla Ozvalda, ki ga zanesljivo lahko označimo kot izrazito andragoško razmišljajočega pedagoga; po njegovih strokovnih pogledih bi bila oznaka, da je andragog, pretirana, saj tedaj še ni bilo strokovnjakov s takšnim nazivom (gl. Ozvald, 1927, str. 7). Ozvalda lahko označimo kot našega, slovenskega očeta koncepta in strategije vseživljenjskosti učenja. Ob namembni vzgoji daje enako velik pomen nenamembnim vzgojnim in izobraževalnim vplivom, kot pomembno (ali celo najpomembnejšo) funkcijo šolskega pouka pa označi to, da pripravlja na »poznejšo samovzgojo pa lastno izobraževanje, ki se pričenjata šele po končani šoli ter normalno trajata vse do konca življenja« (prav tam, str. 16). Ozvald je morda prvi, ki je v Sloveniji umestil izobraževanje odraslih v sistem, to pa tako, da v njem nima postranske ali podrejene vloge $\mathrm{v}$ primerjavi $\mathrm{z}$ izobraževanjem otrok in mladine. To lahko dobro ponazorimo z njegovo prispodobo drevesa, pri katerem pomenijo: korenine - osnovno izobrazbo; deblo - poklicno ali strokovno izobrazbo; »košata krošnja in na njej bujen cvet in sad « - vse nadaljnje izobraževanje, kar označuje kot »človekovo najvišjo in najredkejšo obliko izobrazbe - , splošno izobrazbo“ ali bolje rečeno, izobrazbo' « (prav tam, str. 201). $\mathrm{S}$ tem v resnici začrta celoten vzgojno-izobraževalni sistem na načelih vseživljenjskosti učenja in izobraževanja. V shemi v prispodobi drevesa lahko prepoznamo zamisel izobraževanja odraslih v dveh pomenih: kot nadaljevalno izobraževanje/učenje in kot nadgradnjo šolskega izobraževanja (osnovnega in poklicnega). Temu logično sledi tudi ustrezna institucionalna razporeditev »javnega vzgojstva«, ki se deli na: ljudske, meščanske in srednje šole - za osnovno izobrazbo; strokovne šole - za poklicno izobrazbo in ljudske visoke šole - za splošno izobrazbo (prav tam). Za Ozvalda sta splošna izobrazba in njeno pridobivanje mogoča le v izobraževanju po šoli, torej z izobraževanjem odraslih. Ustrezno institucionalno strukturo za uresničevanje tega koncepta vidi v dejavnosti ljudskih visokih šol. Avtorju seveda ne smemo pripisovati tega, da se je zavedal celotnega sistema izobraževanja odraslih. Ozvaldovo videnje izobraževanja odraslih je vendarle pomanjkljivo,

4 Njihov ustanovitelj je bil duhovnik Anton Martin Slomšek. Znan je njegov učbenik v slovenskem jeziku »Blaže in Nežica v nedeljski šoli«, izdan leta 1842. 
saj ga bolj ali manj identificira le s pridobivanjem »izobrazbe« ali še bolj točno »splošne izobrazbe «. Ne vidi celote izobraževanja odraslih, s tem pa tudi ne njegove razčlenjenosti in tudi vseh njegovih odnosov in povezanosti z drugimi področji vzgojno-izobraževalnega sistema ne. Res pa je, da mu do celovite slike o izobraževanju odraslih ni manjkalo veliko, le da mnogih delčkov tega sistema še ni znal povezati v celoto; govoril pa je o: šolskem in zunajšolskem izobraževanju; namembnem in nenamembnem ter formalnem in neformalnem izobraževanju; kritičen je do pedagogike (vzgojeslovja), ki zanemarja celotno vzgojo in se omejuje le na »ukoslovje«; kot pomembne za učenje šteje dejavnosti »na področju verskega, gospodarskega, pravnega, socialnega ... življenja«, in »zavestne ideje«, ki jih ljudem posredujejo »šola, dom, prižnica, govorniški oder, časopisje, umetnostne in druge razstave, potovanja, kongresi, družabne prireditve itd.«.; v omrežju institucij postavlja ljudske visoke šole kot organizacijsko in funkcijsko enakovreden del sistema vzgoje in izobraževanja, vrednostno pa jih postavlja celo višje, ne pozabi pa tudi na »nedeljske šole« in jih označuje kot »znanilke možnosti, da se šolska obveznost raztegne prek mejnikov ljudskošolske dobe« (prav tam, str. 193), in kot institucije, ki mašijo pomanjkljivosti neustrezno razvitega sistema šolanja. ${ }^{5} \mathrm{~V}$ svojem delu (Jelenc 2016, str. 104) ocenjujem, da »se lahko Slovenci štejemo med tiste narode, ki po poznavanju mogočih konceptualnih in sistemskih rešitev o izobraževanju odraslih vsaj na akademski ravni ${ }^{6} \mathrm{v}$ začetku dvajsetega stoletja nismo zaostajali za najbolj razvitimi narodi sveta. Seveda pa ti pogledi niso bili tudi ustrezno udejanjeni v praksi. Praksa in v povezavi z njo tudi sistem izobraževanja ter pojmovanja drugih tedaj delujočih pedagogov o izobraževanju odraslih pri nas pa so tekli svojo pot, kot da bi jim ne bil Ozvald ničesar ponudil«.

\section{V obdobju med obema vojnama}

V obdobju med prvo in drugo svetovno vojno je bilo izobraževanje odraslih izrazito podrejeno potrebam organizacij, ki so ga organizirale; to pomeni, da je služilo bodisi prosvetljevanju bodisi kakemu drugemu izpopolnjevanju in usposabljanju članov organizacij (Andoljšek, 1964). Gre torej za nadaljevanje utilitarističnega koncepta izobraževanja odraslih, kakršnega poznamo že iz druge polovice 19. stoletja. Andoljšek (1964, str. 197) označuje izobraževanje odraslih kot »dejavnost razrednega značaja « in ugotavlja, da tedanji vladajoči razred ni skrbel zanj, saj mu večja izobraženost delavstva ni bila potrebna in jo je prej preprečeval kot spodbujal. Država si je prizadevala predvsem za odpravljanje nepismenosti, na ljudskih univerzah, ki so se v Sloveniji začele razvijati po letu $1922,{ }^{7}$ pa

\footnotetext{
5 Po svojem videnju vzgoje in izobraževanja kot vseživljenjskega procesa spada Ozvald med pionirje tega pojmovanja $\mathrm{v}$ svetu, saj je te poglede razlagal in tudi objavil v istem času kot tisti svetovni misleci, ki jim $\mathrm{v}$ razvoju in zgodovini izobraževanja odraslih pripisujejo prvenstvo pri uveljavljanju ideje o vseživljenjskosti učenja. To sta zlasti Eduard Lindeman v ZDA s svojim delom The Meaning of Adult Education iz leta 1926 (Jarvis, 1987, str. 141) in Basil A. Yeaxlee v Veliki Britaniji, ki je svoje delo Lifelong Education objavil leta 1929 (Jarvis, n. d., str. 61). Ozvald pa je objavil svojo Kulturno pedagogiko že leta 1927.
}

6 Karel Ozvald je bil profesor pedagogike na ljubljanski univerzi v obdobju med obema svetovnima vojnama; za profesorja je bil izvoljen leta 1920.

7 Tedaj je začela v Mariboru delovati prva ljudska univerza v Sloveniji, do druge svetovne vojne pa jih je nastalo še pet. 
so potekali tudi drugi vzgojno-izobraževalni in prosvetljevalni programi, kot so zdravstveno in gospodarsko prosvetljevanje ter poljudna predavanja, jezikovni tečaji ter tečaji za širše vsakdanje potrebe ljudi (npr. gospodinjski tečaji, tečaji šivanja ipd.).

\section{V obdobju po drugi svetovni vojni}

Potrebo po sistematičnem oblikovanju in zgraditvi andragoške prakse in teorije, ki bi tvorila del celotnega sistema vzgoje in izobraževanja, so prvič v zgodovini razvoja izobraževanja (odraslih) v Sloveniji tudi javno razglašali šele po letu 1952. Sistem in koncept izobraževanja odraslih v tem času nastajata kot rezultat vzajemnega delovanja državne in politične oblasti, njuno oblikovanje pa pogojujejo tako potrebe po izobraževanju delavcev kot tudi potrebe po izobraževanju vsega prebivalstva. Obe navedeni smeri se zdita dovolj široka podlaga za oblikovanje res celovitega sistema izobraževanja odraslih, v tem času pa se, vsaj v začetku, še ne razvija z zornega kota in filozofije vseživljenjskosti učenja. Za njegovo ustrezno teoretsko koncipiranje je šele postopoma bilo mogoče uporabiti nova strokovna spoznanja, ki so se takrat pospešeno porajala v svetu in tudi v Jugoslaviji, zvezni državi, ki ji je tedaj pripadala Slovenija. ${ }^{8}$ Obdobje med letoma 1952 in 1960 lahko označimo kot obdobje relativnega razcveta izobraževanja odraslih v Sloveniji in njegovega sorazmerno ustreznega sistemskega izgrajevanja. V tem času prihaja do jasne členitve izobraževanja odraslih na tri sorazmerno samostojne dele, to so šole za odrasle, delavske univerze in centri za izobraževanje delavcev v gospodarskih organizacijah. Ta struktura je bila tudi zakonsko potrjena s Splošnim zakonom o šolstvu (leta 1958). Navedena institucionalna sestava sicer ne vsebuje vseh mogočih razsežnosti organiziranosti (področij, institucij in njihovega omrežja, dejavnosti) izobraževanja odraslih - manjkala je, denimo, izobraževalna dejavnost različnih prostovoljskih organizacij, bodisi kulturnih bodisi političnih, delavskih, gospodarskih, kmetijskih, verskih, vojaških itn. ter prek medijev, je pa to nedvomno že tista minimalna sestava, ki nam omogoča, da govorimo o izobraževanju odraslih kot posebnem podsistemu v celotnem sistemu vzgoje in izobraževanja. Vsaj na deklarativni ravni so ga po pomenu izenačevali z drugim podsistemom, izobraževanjem otrok in mladine. To je bilo zapisano tudi v najpomembnejših političnih dokumentih, ki so opredeljevali vzgojno-izobraževalno politiko, kot je bila Resolucija o izobraževanju strokovnih kadrov (sprejeta v zvezni ljudski skupščini leta 1960). Ta trend je dosegel svoj vrh s prav tako političnim dokumentom, Resolucijo ZKJ o enotnem družbenem sistemu vzgoje in izobraževanja in o nalogah komunistov pri tem (1974). Temeljni ton temu obdobju razvoja našega izobraževanja odraslih sta dajali dve področji: strokovno in poklicno izobraževanje ter družbenopolitično izobraževanje. ${ }^{9} \mathrm{Ni}$ pa v teh dokumentih

\footnotetext{
8 Razvoj izobraževanja odraslih sta v šestdesetih in sedemdesetih letih zakoličili Unescovi mednarodni konferenci o izobraževanju odraslih v Montrealu in Tokiu. Ta spoznanja so k nam uspešno prenašali teoretiki z univerz v Beogradu, Zagrebu in na Reki (Dragomir Filipović, Borivoje Samolovčev, Dušan Savićević, Mihajlo Ogrizović, Mladen Zvonarević, Martin Petančić, Silvije Pongrac in drugi) ali delujoči pri Unescu (Ašer Deleon). Na navedenih konferencah so že jasno opredelili, da je najširši okvir izobraževanja odraslih vseživljenjskost učenja.

9 Uporabljam izraz, ki se je uporabljal takrat, sicer pa to področje označujemo v strokovni literaturi kot »državljansko izobraževanje« ali »državljansko vzgojo«, izraz, ki je v veljavi povsod po svetu.
} 
povezanost obeh sistemov, vzgoje in izobraževanja otrok in mladine ter izobraževanja odraslih, kot področij vseživljenjskosti učenja niti nakazana, kaj šele jasno opredeljena (Andoljšek, 1964; Pediček, 1985, 1988).

Strokovno in poklicno izobraževanje odraslih, zlasti zaposlenih, je bilo v Sloveniji - če ga primerjamo z razvitostjo $\mathrm{v}$ drugih delih države (Jugoslavije) - najmočneje razvito. Za njegov razvoj so skrbele posebne strokovne razvojno pospeševalne ustanove. ${ }^{10} \mathrm{~S}$ tem je bila povezana posebna skrb za razvoj andragoških kadrov, vendar v tistem času le za potrebe gospodarskih organizacij in centrov za izobraževanje delavcev. ${ }^{11}$ Poglavitni nosilec razvoja tega področja izobraževanja odraslih pri nas je bil Ivan Bertoncelj (gl. Jelenc, 2016, str. 106). Drugo področje - družbenopolitično izobraževanje - pa je izhajalo iz ciljev tedanje družbenopolitične ureditve, za katero je bilo značilno udejanjanje ciljev socialistične revolucije in ideološko-politično oblikovanje ljudi, da bi ti postali njeni zvesti pripadniki, nosilci in zagovorniki.

Po Andoljšku (1964, str. 176-177, 180-181, 200) lahko povzamemo: družba se je zavedala potrebe po skrbi za izobraževanje odraslih in država je prevzemala tudi naloge in odgovornost za to področje, vsaj načeloma enako kot za »redno šolstvo«; identificirajo se subjekti in dejavnosti, ki sestavljajo »zaokrožen sistem izobraževanja odraslih, ki je sestavni del vzgojno-izobraževalnega sistema v SFRJ [Socialistični federativni republiki Jugoslaviji] « (prav tam, str. 181). Izobraževanje odraslih je bilo spoznano kot pomembno področje za zadovoljevanje potreb tako gospodarstva kot tudi družbe v celoti in je bilo kot takšno upoštevano pri sestavi družbenih razvojnih načrtov; področje so urejali splošni in posebni zakoni za vzgojo in izobraževanje, pri tem se je opozarjalo na njegove posebnosti; imelo je tudi svoje upravne resorje; za razvoj izobraževanja odraslih so skrbele posebne strokovne razvojno pospeševalne ustanove, posebna skrb je bila namenjena tudi razvoju andragoških kadrov; krepila sta se zavedanje in odgovornost vseh ustanov za izobraževanje »prosvetnih delavcev«, da se usposabljajo za izobraževanje odraslih in spoznavajo posebnosti tega izobraževanja. A razvoj izobraževanja odraslih so bolj kot lepa načela usmerjale realne družbene in gospodarske razmere, te pa so določali zlasti tile neugodni dejavniki: šibka gmotna podlaga za optimalen razvoj tako gospodarstva kot tudi družbenih dejavnosti; šibke kadrovske zmogljivosti za sorazmerno velike potrebe po izobraževanju odraslih; k enoumju naravnan državni in politični sistem s poudarkom na centralizaciji odločanja; bolj kot za zadovoljitev resničnih (osebnih) potreb človeka in objektivno spoznanih mnogovrstnih družbenih potreb je šlo za zadovoljitev političnih potreb (izgradnja socialistične družbe in človeka); takšna skrb za urejanje področja, ki daje dominanten položaj le dvema segmentoma izobraževanja, za druge pa je »ideološko

10 To sta bila zlasti leta 1958 ustanovljeni Zavod za proučevanje izobraževanja odraslih Ljudske republike Slovenije (LRS) in že leta 1956 ustanovljeni Zavod za proučevanje organizacije dela in varnosti pri delu LRS (od leta 1960 dalje Zavod LRS za produktivnost dela).

11 Nosilka te dejavnosti je bila leta 1960 ustanovljena Višja kadrovska šola pri Zavodu za izobraževanje kadrov in proučevanje dela v Kranju. Šola se je kasneje še večkrat preimenovala, najprej v Višjo, potem v Visoko šolo za organizacijo dela, zdaj pa deluje pod imenom Fakulteta za organizacijske vede v sestavi Univerze v Mariboru. 
slepa«, ne omogoča celovite sistemske ureditve, tudi če je načelno, v programskih in političnih dokumentih, zapisano drugače. Ker so pri udejanjanju sistemskega urejanja izobraževanja odraslih prevladale realne okoliščine in vplivi, je seveda končni izid takšnega koncipiranja in sistemskega urejanja izobraževanja odraslih spet nepopoln in enostranski.

Po oceni Franca Pedička (1988, str. 88) je v drugi šolski reformi ${ }^{12}$ vsaj na področju strokovnega in poklicnega izobraževanja bila dosežena dokajšnja stopnja enakopravnosti izobraževanja odraslih z izobraževanjem otrok in mladine; gledano z zornega kota vseživljenjskosti učenja, nadaljevalnega in začetnega izobraževanja, se izobraževanju odraslih daje pomembno mesto pri oblikovanju celotnega sistema vzgoje in izobraževanja. To vidi avtor zlasti pri opredeljevanju sistemske ureditve in vloge vzgojno-izobraževalnih centrov, ki jih oblikovalci druge šolske reforme po njegovi oceni razumejo kot »pluralistično zasnovane« institucije, ki ne le da dopolnjujejo sistem srednjega šolstva, temveč so tudi »organizacije, ki so vključene v sistem izobraževanja odraslih« in zadovoljujejo njegove zelo različne potrebe ter so »organizacijsko-funkcionalne integracije srednjega in visokega strokovnega šolstva«. Avtor ocenjuje, da je tu najbolj mogoče najti stično točko med podsistemoma vzgoje in izobraževanja otrok in mladine ter izobraževanjem odraslih, to pa presega tedaj še precej prevladujoče pojmovanje izobraževanja odraslih kot tistega področja v sistemu vzgoje in izobraževanja, ki ima predvsem kompenzacijsko funkcijo. Žal se v nadaljevanju, ki ga je najbolj zaznamovalo obdobje t. i. usmerjenega izobraževanja, te pozitivne ocene in napovedi za sistemsko umestitev izobraževanja odraslih in njegov obetavni razvoj niso udejanjile; zmagala je negativna opcija, kar je izobraževanje odraslih postavljalo v marginalen položaj v sistemu. Nadrobnejše analize o uresničevanju reforme - t. i. samoupravne družbene preobrazbe vzgoje in izobraževanja v sistemu socialističnega samoupravnega družbenega sistema - nam pokažejo, da sta kljub lepo zvenečim načelom in izhodiščem celotne reforme imeli za razvoj izobraževanja odraslih neugoden vpliv zlasti dve izhodišči: zahteva po oblikovanju enotnega družbenega sistema vzgoje in izobraževanja, po kateri naj bi se vse vrste vzgoje in izobraževanja v državi, med temi tudi izobraževanje odraslih, povezale v enovit sistem, in zahteva po tesni povezanosti vzgoje in izobraževanja z delom v t. i. združenem delu, da bi tako dosegli boljšo medsebojno povezanost med izobraževanjem in delom.

Navidezno pozitivno naravnani prvini oziroma načeli za razvoj sistema vzgoje in izobraževanja - niti enotnosti sistemskega urejanja niti večjega povezovanja med izobraževanjem in delom na splošno ne bi mogli zavrniti kot negativni in škodljivi načeli, saj odpirata pot $\mathrm{k}$ večjemu povezovanju $\mathrm{v}$ sistemski ureditvi vzgoje in izobraževanja - sta v danih zgodovinskih in družbenih razmerah na izobraževanje odraslih delovali neugodno. Kasnejši razvoj je pokazal, da je zamisel t. i. sistema usmerjenega izobraževanja, ki je bil legaliziran leta 1980, po nekaj letih spričo ostrih kritik in nasprotovanja propadla, izobraževanju odraslih pa je tudi teh nekaj let prineslo nazadovanje tako v sistemski ureditvi kot v praksi (Jelenc, 1997, str. 231-241; 2000, str. 61-63). Pokazalo se je, da zgolj ideološko

12 Potekala je v obdobju 1961-1970, medtem ko je prva, po ugotovitvah avtorja, potekala pet let pred tem, v obdobju 1955-1960. 
in politično zasnovan projekt brez ustreznega sodelovanja in upoštevanja stroke, andragogike in izobraževanja odraslih, ne vodi k uspehu. Žal je v tem obdobju izobraževanje odraslih celo nazadovalo: enotnost se je uravnavala po šolsko pedagoških modelih, še bolj kot prej (Slovenija je država z močno šolsko pedagoško tradicijo) je zavladala šolska pedagoška doktrina, rezultat tega pa je bilo hudo »pošolanje « izobraževanja odraslih, ki je imelo precej zaznavne in očitne neugodne posledice: izpeljava programov izobraževanja (zlasti programov za pridobitev izobrazbe) $\mathrm{v}$ šolah bolj kot $\mathrm{v}$ posebnih ustanovah za izobraževanje odraslih je povzročila občuten upad vpisov v izobraževanje in $s$ tem zmanjšanje števila udeležencev formalnega izobraževanja skoraj za polovico; ${ }^{13}$ razpuščeni so bili posebne razvojne službe in središča za izobraževanje odraslih, češ da lahko te naloge enako dobro opravijo skupne ali enotne službe in središča; ${ }^{14}$ razveljavljen je bil posebni zakon za izobraževanje odraslih, češ da lahko izobraževanje odraslih določajo skupni zakoni (Zakon o usmerjenem izobraževanju) $;^{15}$ opuščali so se posebni programi za izobraževanje odraslih.

Enotnost seveda lahko pomeni tudi odpravljanje različnosti in prav to se je začelo dogajati z izobraževanjem odraslih. Njegove posebnosti, na katere se je v prvem reformnem obdobju še posebej opozarjalo, so postale nepomembne, iskalo se je le ali predvsem poti $\mathrm{k}$ sistemskemu poenotenju; to pa je v pretežnem delu izobraževanja odraslih vodilo $\mathrm{k}$ njegovemu pošolanju. Pri povezovanju izobraževanja $\mathrm{z}$ delom pa je na razvoj odločilno vplivalo to, za kakšno funkcionalno zvezo je šlo ter v kakšnih tehnoloških, organizacijskih in družbenopolitičnih razmerah je potekalo to povezovanje. Žal je treba ugotoviti, da razmere pri ključnih vprašanjih, kot so stopnja tehnološkega razvoja, cilji in organiziranost gospodarstva, strokovna razgledanost in usposobljenost odločujočih kadrov ter seveda ideološka in politična usmerjenost in organiziranost družbe, niso omogočale pozitivne izpeljave navedenega izhodišča - povezovanja izobraževanja z delom. ${ }^{16}$ Financiranje

13 S tem so bile prizadete tudi ljudske univerze, izvajalke in organizatorke tudi programov izobraževanja za pridobitev izobrazbe ali drugega strokovnega znanja. Te programe so ali naj bi v obdobju usmerjenega izobraževanja prevzemale le šole, kar je poslabševalo možnosti za udeležbo odraslih v izobraževanju (oddaljenost, neustrezna izpeljava, neprivlačnost ter neustreznost kraja in časa izobraževanja itn.).

14 Razpuščena je bila posebna razvojna enota (sektor) za izobraževanje odraslih na Zavodu za šolstvo, ki je štela od tri do sedem svetovalcev in je imela omrežje posebnih svetovalcev za izobraževanje odraslih po vseh enotah zavoda; tako je izobraževanje odraslih v Sloveniji po letu 1980 v celoti ostalo brez svoje razvojne infrastrukturne dejavnosti.

15 S sprejetjem Zakona o usmerjenem izobraževanju je leta 1980 prenehal veljati Zakon o delavskih univerzah, izobraževalnih centrih in drugih organizacijah za izobraževanje odraslih, ki se poleg šol ukvarjajo z izobraževanjem, in ki je posebej urejal status in delovanje organizacij za izobraževanje odraslih. Sprejet je bil leta 1971, od leta 1977 dalje pa se je imenoval Zakon o organizacijah za izobraževanje odraslih (Uradni list RS, 1977). Z njegovo razveljavitvijo se je izgubilo nekaj specifičnosti pri sistemskem urejanju izobraževanja odraslih.

16 Povezovanje izobraževanja in dela - v razmerah, kakršne smo že opisali - je botrovalo nekaterim za izobraževanje odraslih neugodnim posledicam, kot so bile: neugodna sestava programov izobraževanja delavcev v delovnih organizacijah, saj so pri izobraževanju v delovnih organizacijah močno prevladovali programi usposabljanja za manj zahtevna dela in različni splošni programi družbenopolitičnega in splošnega izobraževanja, malo pozornosti pa se je namenjalo razvojno naravnanim programom za vodstvene delavce in razvojne ter strokovne službe; malo je bilo programov za specializacije in programov za zviševanje izobrazbe za zahtevnejša dela (Jelenc, 1994, str. 18-20). 
izobraževanja odraslih z javnimi sredstvi je domala povsem usahnilo, saj je bilo prepuščeno t. i. neposredni svobodni menjavi dela, o kateri so odločale delovne organizacije; ker pa te niso bile dovolj ozaveščene o potrebah po izobraževanju odraslih, je bilo iz tega naslova za kakovostno izobraževanje odraslih namenjenega sorazmerno malo denarja; nekatere analize pa so pokazale, da se je denar za izobraževanje po tem sistemu sorazmerno neracionalno porabljal (Jelenc, 1994). Družbene potrebe so bile pomembnejše od prioritet posameznika, zato je bilo malo pozornosti namenjene razvijanju možnosti posameznika, da bi se izobraževal v skladu s svojimi lastnimi potrebami. V nasprotju s tem pa je bila zelo velika ponudba, lahko rečemo tudi prisila, pri izobraževanju za družbene potrebe, kot so bili znani programi družbenopolitičnega in idejnopolitičnega izobraževanja ter mnogi programi splošnega izobraževanja, za katere so družba in organizacije presodile, da bi koristili posamezniku. Bilo je premalo družbenih in finančnih spodbud za razvoj stroke in andragoške znanosti.

Vendar se je izobraževanje odraslih kljub opisanim neugodnim družbenopolitičnim okoliščinam ter nezadostni in neustrezni družbeni podpori razvijalo sorazmerno uspešno in $\mathrm{v}$ skladu z razvojem v svetu. Strokovnjakom, ki so se z izobraževanjem odraslih ukvarjali v sedemdesetih in osemdesetih letih 20. stoletja, niso bile neznane ugotovitve in priporočila Unescovih konferenc o izobraževanju odraslih, zlasti tokijske, ki smo jo označili za prelomno. V tem času so se v Sloveniji, poleg že navedenega strokovnega in poklicnega izobraževanja odraslih, uspešno razvijale delavske univerze, ki so imele strokovno zelo močno in kompetentno strokovno službo v Zvezi delavskih univerz. ${ }^{17}$ Izobraževalci odraslih so se izobraževali najprej na Fakulteti za industrijsko pedagogiko na Reki, a od leta 1972 so lahko predmet andragogika poslušali tudi že v Ljubljani na Oddelku za pedagogiko.

Pomembno vlogo pri razvoju izobraževanja odraslih v Sloveniji je v naslednjih letih imela ustanoviteljica programa andragogike na Filozofski fakulteti v Ljubljani dr. Ana Krajnc. Pridružila se je vodilnim jugoslovanskim andragogom, ki so delovali na univerzah v Beogradu in Zagrebu, povezovali pa so se tudi v Zvezi andragoških društev Jugoslavije. Na pobudo tega združenja je bilo v Sloveniji leta 1968 ustanovljeno Andragoško društvo Slovenije, pomemben dejavnik pri razvoju izobraževanja odraslih v Sloveniji, katerega delovanje je bilo zelo intenzivno v osemdesetih letih, potem ko so leta 1984 na posvetu na Bledu sprejeli Dolgoročni program razvoja izobraževanja odraslih v Sloveniji. Ta program je bil pomembna podlaga za razvoj izobraževanja odraslih v naslednjih letih; postavil je cilje in smernice ter opredelil dejavnosti, ki so se začeli pomembneje udejanjati po letu 1991, ko je Slovenija postala samostojna država (Izobraževanje odraslih ..., 1985, str. 80-95).

\section{V obdobju po osamosvojitvi Slovenije}

Pospešen razvoj izobraževanja odraslih so v novonastali državi Sloveniji omogočili tile sistemski ukrepi: v državnem proračunu so bila odobrena posebna sredstva za izobraževanje

17 Med strokovno najmočnejšimi osebnostmi omenimo Tilko Blaha in Jožeta Valentinčiča, ki sta zasedala vodstvene položaje $\mathrm{v}$ Zvezi delavskih univerz in sta bila strokovno zelo razgledana ter dobro poučena o razvoju izobraževanja odraslih v svetu. 
odraslih; na tedanjem ministrstvu za šolstvo je bila ustanovljena posebna enota, ki je kasneje prerasla v sektor za izobraževanje odraslih; v letu 1996 je bil sprejet poseben zakon o izobraževanju odraslih skupaj z nekaterimi drugimi akti v t. i. šolski zakonodaji, ki je vsebovala tudi zakonske rešitve za izobraževanje odraslih; ustanovljena je bila posebna strokovna ustanova za razvoj in pospeševanje razvoja izobraževanja odraslih - Andragoški center Slovenije; zasnovan je bil nacionalni program za izobraževanje odraslih, ki ga je financirala vlada s posebnimi sredstvi; pri ministrstvu za šolstvo in šport je bil ustanovljen strokovni svet za izobraževanje odraslih; na Filozofski fakulteti Univerze v Ljubljani je nastal sorazmerno samostojen program za študij andragogike. Vse to je izjemno pospešilo razvoj izobraževanja odraslih v Sloveniji, kjer so v naslednjih letih stekli številni razvojni in raziskovalni programi ter programi za spopolnjevanje znanja izobraževalcev odraslih in drugega osebja na ustanovah za izobraževanje odraslih. Začele so delovati številne zasebne organizacije za izobraževanje odraslih, nastala so nova združenja za izobraževanje odraslih, začela je izhajati strokovna in znanstvena revija za izobraževanje odraslih - Andragoška spoznanja. Številni razvojni projekti, kot so študijski krožki, središča za samostojno učenje, projektno učenje za mlade, borza znanja, programi usposabljanja za življenjsko uspešnost, teden vseživljenjskega učenja in parada učenja, informacijska in svetovalna središča za izobraževanje odraslih, programi za ugotavljanje in potrjevanje znanja ter drugi so bili v najširšem smislu namenjeni razvijanju in pospeševanju kulture učenja. To pa so nekakšni temeljni kamni za razvoj in udejanjanje filozofije vseživljenjskosti učenja s poudarkom na izobraževanju odraslih, ki so, vsaj nekateri, vključevali tudi učenje otrok in mladine ter pospeševali tudi njihovo učenje (Jelenc, 2000; 2016).

Nekakšen krovni dosežek, gledano z zornega kota vseživljenjskosti učenja, je bilo sprejetje Strategije vseživljenjskosti učenja v Sloveniji leta 2007 pri ministrstvu za šolstvo. Žal ministrstvo ni upoštevalo priporočila posebne skupine, ki je pripravljala strategijo, ${ }^{18}$ da bi dokument in tudi odgovornost za udejanjanje strategije sprejeli na vladi. Druga pomanjkljivost ob sprejetju strategije je bila, da ni bil upoštevan eden od ukrepov za njeno udejanjanje, to je sprejetje Operativnega programa za udejanjanje strategije. Skupina je sicer pripravila tudi tega, vendar ga ministrstvo ni niti obravnavalo, seveda tako ni mogel biti uradno sprejet. ${ }^{19} \mathrm{~V}$ letu po sprejetju strategije je ministrstvo imenovalo strokovni svet (to je bil eden od v strategiji predlaganih ukrepov), vendar so svet sestavljali le predstavniki (uradniki) ministrstev, imel pa je eno samo sejo, kar dokazuje, da ukrep ni bil resno zastavljen.

Čeprav je bila Strategija vseživljenjskosti učenja v Sloveniji politično potrjena in priznana ter je bilo tako sprejeto tudi to, da sistem vzgoje in izobraževanja sestavljata dve

18 Skupino je vodil dr. Zoran Jelenc, ki je tudi oblikoval končno besedilo.

19 Naslov predloženega dokumenta je »Pregled dejavnosti za udejanjanje Strategije vseživljenjskosti učenja«. Obsega 74 ukrepov, ki so razdeljeni na tri skupine: a) dejavnosti, ki so skupne za celotno strategijo (23 točk), b) dejavnosti za obdobje začetnega izobraževanja (15 točk) in c) dejavnosti za obdobje nadaljevalnega izobraževanja (36 točk). Dejavnosti so opredeljene tudi po tem, na kakšen način naj bi jih izvedli (normativne rešitve, naloge strokovnih ustanov ali služb in raziskovalne naloge) in kako bi jih izvedli časovno (kratkoročno, srednjeročno ali permanentno). 
enakovredni področji - izobraževanja otrok in mladine ter izobraževanja odraslih - vzgojno-izobraževalna politika in sistemska ureditev ne delujeta tako, kot je teoretično opredeljeno. Izobraževanje odraslih je še naprej pomanjkljivo sistemsko urejeno ali, bolje rečeno, ni urejeno. Vseživljenjskost učenja je še naprej pojem, ki ga politiki uporabljajo le politično, za svojo promocijo, v praksi pa se ne udejanja. Za njegovo udejanjanje se potegujejo le ali predvsem andragogi, pedagogi ter izobraževalci otrok in mladine. Njihovi politični zastopniki pa se sploh nikoli niso potegovali za strategijo in priznanje vseživljenjskosti učenja, saj je izobraževanje odraslih ali »nadaljevalno izobraževanje« zanje predvsem konkurenčni porabnik že tako omejenih in nezadostnih finančnih sredstev. ${ }^{20}$

Tako kljub sorazmerno uspešnemu razvoju v praksi ostajamo pri kritični oceni, da smo pri sistemskem urejanju izobraževanja odraslih še vedno na ravni, na kateri smo bili pred tremi ali štirimi desetletji. Tu lahko pričakujemo napredek šele, ko bomo zares sprejeli in udejanjili na ministrstvu za izobraževanje sprejeto Strategijo vseživljenjskosti učenja v Sloveniji, ki je za zdaj še zmeraj mrtva črka na papirju. ${ }^{21}$ Udejanjenje strategije bi na politični in sistemski ravni zahtevalo, da vseživljenjskost učenja postane »vodilno načelo vsega izobraževanja in učenja ter temeljna družbenorazvojna strategija« (Jelenc, 2007, str. 7).

Izobraževanje odraslih ni ustrezno sistemsko umeščeno, kot bi kot komplementarno področje v celotnem sistemu vzgoje in izobraževanja moralo biti, in je zapostavljeno v vseh sferah sistemskega urejanja (upravljanje, zakonodaja, financiranje, razvoj omrežja izvajalcev in programov ter infrastruktura). Teoretične študije povedo (npr. Pediček, 1992; Jelenc, 2000), da je izobraževanje odraslih dejavnik ocelotenja sistema vzgoje in izobraževanja; brez njega strategije vseživljenjskosti učenja ni, pa tudi nasprotno, brez strategije vseživljenjskosti učenja izobraževanje odraslih ne more postati enakovreden in koherenten sistem v vzgoji in izobraževanju. Da to ni, dokazujejo kratki opisi zdajšnjih pomanjkljivosti sistemske (ne)urejenosti izobraževanja odraslih.

\section{Upravljanje}

Še pred nekaj leti se je pristojno ministrstvo imenovalo ministrstvo za šolstvo in šport (in ne za vzgojo in izobraževanje, kot je to v večini drugih držav); direktorati ministrstva se pri nas oblikujejo po stopnjah šolanja - za osnovno, srednjo itn. šolo. Izobraževanje odraslih, ki je v več kot 90 odstotkih zunajšolska dejavnost, iz takšnega sistema upravljanja izpade - v zdajšnjem ministrstvu za izobraževanje, znanost in šport nima svojega direktorata (je le sektor v sestavi direktorata za srednje in višje šolstvo ter izobraževanje odraslih!) in zato tudi nima svojega predstavnika v kolegiju ministra.

20 Takšno pojmovanje se dobro zrcali v uradni uporabi in priznavanju izrazov »redno« (za izobraževanje otrok in mladine) in »izredno« (za izobraževanje odraslih), kar nima le simboličnega pomena.

21 Tudi v strateškem dokumentu Vizija Slovenije, ki napoveduje razvoj Slovenije do leta 2050, navajajo med poglavitnimi stebri vizije na prvem mestu »učenje za in skozi vse življenje, ki nam bo omogočilo, da bomo tudi leta 2050 ustvarjali številne uspešne zgodbe, da se bo Slovenija lahko predstavljala kot inovativna ali celo država z edinstvenim razvojnim modelom v svetu « (Delo, 10. 2. 2017, str. 10). Tudi tedanja ministrica za vzgojo in izobraževanje, tehnologijo in šport, dr. Maja Makovec Brenčič, je v svojem komentarju dokumenta navedla (prav tam), da »naša skupna prihodnost temelji na vseživljenjskem učenju«. 


\section{Zakonodaja}

Zakonodajo kroji enaka (šolska) logika (̌̌olanje po stopnjah), zato jo pretežno sestavljajo »šolski« zakoni. ${ }^{22}$ Zakon o izobraževanju odraslih iz leta 1996 je pomanjkljiv, izobraževanja odraslih ne obravnava celostno, temveč obravnava le neformalno izobraževanje. Ta fragmentacija se nadaljuje tudi v novem Zakonu o izobraževanju odraslih iz leta 2018. Formalno izobraževanje odraslih ostaja $\mathrm{v}$ šolski domeni. Zakonodaja izobraževanja odraslih ne vidi kot specifično področje vzgoje in izobraževanja in kot koherenten sistem.

\section{Financiranje}

Financiranje privilegira vzgojo in izobraževanje otrok in mladine; prioriteta so šole ter otroci in mladina, izobraževanje odraslih v precejšnjem delu prepušča posamezniku in njegovim delodajalcem; lokalnih skupnosti zakonsko ne obvezuje za financiranje, razen osnovnošolskega izobraževanja, ki pa ima v celotnih stroških in potrebah po izobraževanju odraslih zanemarljiv delež (gl. tudi Kump, 2017).

\section{Omrežje izvajalcev in programov ter infrastruktura}

Tudi to je prilagojeno šolski logiki; področje izobraževanja odraslih se že leta bojuje za to, da bi mu bili priznani javno veljavni programi, kot jih imajo otroci in mladina, kjer so njihovi izvajalci šole. Izvajalci izobraževanja odraslih so prepuščeni delovanju trga in so odvisni od povpraševanja uporabnikov. Podobno neizenačeni sta področji tudi pri razvoju in delovanju infrastrukture.

\section{ZAKLJUČEK}

Izobraževanje odraslih v Sloveniji je bilo nedvomno ves čas seznanjeno z razvojem izobraževanja odraslih v svetu. To velja tako za zgodnje obdobje njegovega razvoja (pozni srednji vek in začetek novega veka, začetek 20. stoletja) kot tudi za novejša obdobja (obdobje med obema vojnama in po drugi svetovni vojni), ko se je tesno povezovalo z razvojem izobraževanja odraslih v nekdanji Jugoslaviji. Zelo specifičen pa je njegov razvoj po osamosvojitvi Slovenije, ko področje napreduje hitreje kot v drugih državah, nastalih na območju nekdanje Jugoslavije, in se bolj neposredno zgleduje po smernicah EU ter po že prej znanih usmeritvah Unesca, OECD in Svetovne banke. V tem obdobju se v Sloveniji tudi neposredno uveljavijo spoznanja iz Kanade in ZDA, ki jih k nam uspešno in osebno prenesejo andragogi (zlasti Ana Krajnc in Zoran Jelenc) s svojih študijskih obiskov v Severni Ameriki in Evropi.

V Sloveniji smo bili po zaslugi zlasti dveh oseb - pedagoga Karla Ozvalda ter pedagoginje, psihologinje in andragoginje Ane Krajnc - zlasti v dveh obdobjih, najprej po prvi in nato po drugi svetovni vojni, med nosilci in pionirji andragoških spoznanj. Karla Ozvalda lahko po njegovih sistemskih razmišljanjih in pojmovanjih v knjigi Kulturna

22 Poglavitni zakon za področja vzgoje in izobraževanja je Zakon o organizaciji in financiranju vzgoje in izobraževanja, ki je ukrojen po šolski logiki. 
pedagogika (1927) označimo za izrazito andragoško razmišljajočega pedagoga, spada pa med pionirje koncepta in strategije vseživljenjskosti učenja v svetu; v svoji knjigi kritizira pedagoško teorijo, češ da se je predvsem usmerjala v »ukoslovje«, v resnici pa se »izobraževanje pričenja šele po končani šoli ter normalno traja vse do konca življenja«. S tem se je uvrstil med pionirje ideje o vseživljenjskosti učenja v svetu, saj sta bili v tem času (leta 1926 in 1929) v ZDA in Veliki Britaniji objavljeni prvi knjigi, ki govorita o vzgojno-izobraževalnem sistemu, ki temelji na načelih vseživljenjskosti učenja in izobraževanja. Druga za izobraževanje odraslih in andragogiko posebej zaslužna oseba pri nas je Ana Krajnc, ki je leta 1972 na Filozofski fakulteti v Ljubljani vzpostavila program študija andragogike. S tem se je pridružila vodilnim jugoslovanskim andragogom, ki so delovali na univerzah v Beogradu in Zagrebu in so bili dobro seznanjeni z razvojem izobraževanja odraslih v svetu (zlasti Dušan Savićević, Borivoje Samolovčev, Nikola Pastuović, Nikša Nikola Šoljan). Povezave je krepilo njihovo sodelovanje v Zvezi andragoških društev Jugoslavije, na njeno pobudo pa je bilo tudi v Sloveniji leta 1968 ustanovljeno Andragoško društvo Slovenije.

Izobraževanje odraslih v Jugoslaviji je le delno upoštevalo spoznanja svetovno znanih in priznanih andragogov (kot so Knowles, Houle, Lengrand, Freire, Titmus, Tough, Rubenson, Jarvis, če navedemo le nekatere) in jih udejanjalo v praksi. Sistem in koncept izobraževanja odraslih v tem času sta nastajala kot rezultat vzajemnega delovanja državne in politične oblasti, ki je dajala prednost izobraževanju za potrebe delavcev kot tudi t. i. družbenopolitičnemu izobraževanju, ki si za cilj postavlja predvsem oblikovanje socialistične osebnosti; pri tem je bilo zapostavljeno drugo izobraževanje, predvsem za osebne potrebe in prosti čas. V tem obdobju prihaja do jasne členitve izobraževanja odraslih na tri sorazmerno samostojne dele, to so: šole za odrasle, delavske univerze in centri za izobraževanje delavcev v gospodarskih organizacijah, institucionalno pa so zapostavljene zasebne izobraževalne ustanove v primerjavi s tistimi, katerih ustanoviteljica je država. Po letu 1980 je imelo posebno negativne učinke na izobraževanje odraslih t. i. usmerjeno izobraževanje. Na razvoj izobraževanja odraslih sta imeli neugoden vpliv zlasti dve izhodišči: zahteva po oblikovanju enotnega družbenega sistema vzgoje in izobraževanja, po kateri naj bi se vse vrste vzgoje in izobraževanja v državi, med temi tudi izobraževanje odraslih, povezale v enovit sistem, in zahteva po tesni povezanosti vzgoje in izobraževanja z delom v t. i. združenem delu, da bi tako dosegli boljše usklajevanje med izobraževanjem in delom. Navidezno pozitivno naravnani prvini oziroma načeli za razvoj sistema vzgoje in izobraževanja sta $\mathrm{v}$ danih zgodovinskih in družbenih razmerah na izobraževanje odraslih delovali neugodno: zavladala je šolska pedagoška doktrina, rezultat tega je bilo hudo »pošolanje « izobraževanja odraslih in posledično močan upad udeležbe odraslih v izobraževanju; razpuščene so bile posebne razvojne službe in središča za izobraževanje odraslih, razveljavljen je bil posebni zakon za izobraževanje odraslih; opuščali so se posebni programi za izobraževanje odraslih. Pri povezovanju izobraževanja z delom pa številni dejavniki, kot so nizka stopnja tehnološkega razvoja, slaba organiziranost gospodarstva, strokovna nerazgledanost in neusposobljenost odločujočih kadrov ter seveda ideološka in politična usmerjenost in organiziranost družbe, niso dopuščali pozitivne 
izpeljave navedenega izhodišča. Sredstva za izobraževanje v organizacijah niso bila smotrno izrabljena, progami so bolj zadovoljevali manj izobražene delavce, zapostavljeni pa so bili visoko izobraženi in razvojno pomembni delavci.

Po letu 1991, ko je Slovenija postala samostojna država, se je pokazala večja podpora razvoju izobraževanja odraslih, kar je omogočila država z več sistemskimi ukrepi: v državnem proračunu so bila odobrena posebna sredstva za izobraževanje odraslih; ustanovljen je bil sektor za izobraževanje odraslih pri ministrstvu za šolstvo; sprejet je bil posebni zakon o izobraževanju odraslih; ustanovljena je bila posebna strokovna ustanova za razvoj in pospeševanje razvoja izobraževanja odraslih - Andragoški center Slovenije; zasnovan je bil nacionalni program za izobraževanje odraslih, ki ga je financirala vlada s posebnimi sredstvi; ustanovljen je bil svet za izobraževanje odraslih pri ministrstvu za šolstvo in šport, na Filozofski fakulteti Univerze v Ljubljani je nastal sorazmerno samostojen program za študij andragogike. To je omogočilo, da so v naslednjih letih stekli številni razvojni in raziskovalni programi ter programi za spopolnjevanje znanja izobraževalcev odraslih in drugega osebja na ustanovah za izobraževanje odraslih; začele so delovati številne zasebne organizacije za izobraževanje odraslih; nastala so nova združenja za izobraževanje odraslih; začela je izhajati strokovna in znanstvena revija za izobraževanje odraslih - Andragoška spoznanja; številni razvojni projekti, kot so študijski krožki, središča za samostojno učenje, projektno učenje za mlade, borza znanja, programi usposabljanja za življenjsko uspešnost, teden vseživljenjskega učenja in parada učenja, informacijska in svetovalna središča za izobraževanje odraslih, programi za ugotavljanje in potrjevanje znanja in drugi so v najširšem smislu namenjeni razvijanju in pospeševanju kulture učenja. To pa so nekakšni temeljni kamni za razvoj in udejanjanje filozofije vseživljenjskosti učenja s poudarkom na izobraževanju odraslih, ki so, vsaj nekateri, vključevali tudi učenje otrok in mladine in pospeševali tudi njihovo učenje. Z zornega kota vseživljenjskosti učenja je bilo pomembno, da je bila leta 2007 sprejetja Strategija vseživljenjskosti učenja v Sloveniji.

Strategija vseživljenjskosti učenja v Sloveniji je bila sprejeta na pobudo in zahtevo EU. Članicam EU je bilo naročeno, da sprejmejo takšno strategijo, kar dokazuje vpliv EU in evropskih standardov na razvoj tudi izobraževanja odraslih. Žal kljub temu, da je strategija politično potrjena in priznana ter bi se moral sistem vzgoje in izobraževanja oblikovati $\mathrm{v}$ dve enakovredni področji - izobraževanja otrok in mladine ter izobraževanja odraslih - vzgojno-izobraževalna politika in sistemska ureditev ne delujeta tako, kot je teoretično opredeljeno. Izobraževanje odraslih je še naprej pomanjkljivo sistemsko urejeno ali, bolje rečeno, ni urejeno. Zato izobraževanje odraslih kljub sorazmerno uspešnemu razvoju $\mathrm{v}$ praksi ostaja po sistemski ureditvi v vseh sferah (upravljanje, zakonodaja, financiranje, razvoj omrežja izvajalcev in programov ter infrastruktura) še vedno večinoma na ravni, na kateri smo bili pred tremi ali štirimi desetletji. Udejanjenje strategije vseživljenjskosti učenja bi na politični in sistemski ravni zahtevalo, da vseživljenjskost učenja postane »vodilno načelo vsega izobraževanja in učenja ter temeljna družbenorazvojna strategija. Za korenite spremembe bi torej potrebovali novo in temeljito sistemsko preureditev vzgoje 
in izobraževanja z izhodiščem, da vseživljenjskost izobraževanja in učenja ni le nadgradnja današnje sistemske ureditve vzgoje in izobraževanja, temveč povsem nova sistemska ureditev v vseh ključnih sferah sistemskega urejanja. Strategijo vseživljenjskosti učenja bi morala sprejeti vlada republike in je ne bi smeli prepuščati samo enemu ministrstvu, saj je učenje dejavnost, s katero se morajo ukvarjati v vseh vladnih resorjih (učenje je aktualno na vseh področjih) in ne le v »šolskem«, če uporabim to že nekoliko zastarelo poimenovanje, ki ga še zmeraj uporabljajo tako politiki kot mediji.

\section{LITERATURA}

Andoljšek, I. (1964). Izobraževanje odraslih. V Izbrana poglavja iz pedagogike (str. 175-200). Ljubljana: Državna založba Slovenije.

Delors, J. (ur.) (1996). Učenje: skriti zaklad. Poročilo Mednarodne komisije o izobraževanju za enaindvajseto stoletje, pripravljeno za UNESCO. Ljubljana: Ministrstvo za šolstvo in šport.

Izobraževanje odraslih v dolgoročnem razvoju Slovenije : gradivo s posveta Andragoškega društva Slovenije, ki je bil 19. in 20. oktobra 1984 na Bledu (1985). Ljubljana: Delavska enotnost.

Jarvis, P. (ur.) (1987). Twentieth Century Thinkers in Adult Education. London: Rutledge.

Jelenc, Z. (1994). Nekatera teoretska izhodišča, temeljne opredelitve in razmejitve pri koncipiranju izobraževanja odraslih. V Snovanje in sistemsko urejanje izobraževanja odraslih - Splošna izhodišča in primerjalni pregled stanja $v$ Sloveniji (str. 40-61). Ljubljana: Andragoški center Slovenije.

Jelenc, Z. (1997). Zgodovinski razvoj koncepcije in sistemskega urejanja izobraževanja odraslih v obdobju od leta 1945 do leta 1991. V J. Jug (ur.), Prispevki k zgodovini izobraževanja odraslih - (19451990) (str. 231-268). Kranj: Založba Moderna organizacija.

Jelenc, Z. (2000). Strategija in koncepcija izobraževanja odraslih v Sloveniji. Ljubljana: Andragoški center Slovenije.

Jelenc, Z. (2007). Strategija vseživljenjskosti učenja v Sloveniji. Ljubljana: Ministrstvo za šolstvo in šport.

Jelenc, Z. (2016). Vseživljenjskost učenja in izobraževanje odraslih. Nova Gorica: Educa.

Knowles, M. S. (1980). The Modern Practice of Adult Education: From Pedagogy to Andragogy. Englewood Cliffs: Cambridge Adult Education.

Kump, S. (2017). Konec varčevanja? Javno financiranje izobraževanja odraslih. Andragoška spoznanja, 23(1), 3-6.

Ozvald, K. (1927). Kulturna pedagogika. Kažipot za umevanje včlovečevanja. Ljubljana: Slovenska šolska matica.

Pediček, F. (1985, 1989). Razvoj in sistem slovenske pedagoške terminologije. Ljubljana: Pedagoški inštitut.

Pediček, F. (1988). Centri usmerjenega izobraževanja: šolskoreformni okvir in teoretske osnove. Ljubljana: Pedagoški inštitut.

Pediček, F. (1992). Pedagogika danes. Maribor: Obzorja.

Titmus, C. J. (1979): Some Considerations on Relationship between the Parts of Adult Education, at the Level of Macro and Micro Models. Kladno, ECLE Expert Meeting on Out-of-School Adult Education. Konferenčno gradivo, tipkopis, 8 strani.

Titmus, C. J. (ur.) (1989a). Lifelong Education for Adults: An International Perspective. Oxford: Pergamon.

Titmus, C. J. (1989b). The Field of Adult Education. V C. J. Titmus (ur.), Lifelong Education for Adults: An International Perspective (str. 13-18). Oxford: Pergamon. 
Titmus, C. J. (1989c). National Programs and Organisation. V C. J. Titmus (ur.), Lifelong Education for Adults: An International Perspective (str. 381-387). Oxford: Pergamon.

Titmus, C. J. (1996). Adult Education: Concepts and Principles. V A. C. Tuijnman (ur.), International Encyclopedia of Adult Education and Training (str. 9-18). New York: Pergamon.

Unesco (1976). Recommendation on the Development of Adult Education adopted by the General Conference at its Nineteenth Session, Nairobi, 26. november 1976. Paris: Unesco.

Žgeč, F. (1923). Problemi vzgoje najširših plasti našega naroda. Ljubljana: Udruženje jugoslovenskega učiteljstva. 